Notifiable Infectious Diseases Reports

\title{
Reported Cases and Deaths of National Notifiable Infectious Diseases - China, August, 2020
}

\begin{tabular}{|c|c|c|}
\hline Diseases & Cases & Deaths \\
\hline Plague & 2 & 2 \\
\hline Cholera & 5 & 0 \\
\hline SARS-CoV & 0 & 0 \\
\hline Acquired immune deficiency syndrome & 5,166 & 1,560 \\
\hline Hepatitis & 126,950 & 42 \\
\hline Hepatitis A & 1,401 & 0 \\
\hline Hepatitis B & 102,304 & 30 \\
\hline Hepatitis C & 20,520 & 11 \\
\hline Hepatitis D & 19 & 0 \\
\hline Hepatitis E & 1,759 & 0 \\
\hline Other hepatitis & 947 & 1 \\
\hline Poliomyelitis & 0 & 0 \\
\hline Human infection with $\mathrm{H} 5 \mathrm{~N} 1$ virus & 0 & 0 \\
\hline Measles & 119 & 0 \\
\hline Epidemic hemorrhagic fever & 313 & 2 \\
\hline Rabies & 23 & 15 \\
\hline Japanese encephalitis & 69 & 2 \\
\hline Dengue & 55 & 0 \\
\hline Anthrax & 39 & 0 \\
\hline Dysentery & 7,270 & 0 \\
\hline Tuberculosis & 76,423 & 131 \\
\hline Typhoid fever and paratyphoid fever & 830 & 0 \\
\hline Meningococcal meningitis & 4 & 0 \\
\hline Pertussis & 142 & 0 \\
\hline Diphtheria & 1 & 0 \\
\hline Neonatal tetanus & 3 & 0 \\
\hline Scarlet fever & 763 & 0 \\
\hline Brucellosis & 4,972 & 0 \\
\hline Gonorrhea & 10,724 & 0 \\
\hline Syphilis & 46,838 & 9 \\
\hline Leptospirosis & 51 & 0 \\
\hline Schistosomiasis & 10 & 0 \\
\hline Malaria & 57 & 0 \\
\hline Human infection with $\mathrm{H} 7 \mathrm{~N} 9$ virus & 0 & 0 \\
\hline COVID-19* & 721 & 0 \\
\hline Influenza & 12,833 & 0 \\
\hline Mumps & 9,008 & 0 \\
\hline
\end{tabular}


Continued

\begin{tabular}{|c|c|c|}
\hline Diseases & Cases & Deaths \\
\hline Rubella & 96 & 0 \\
\hline Acute hemorrhagic conjunctivitis & 2,561 & 0 \\
\hline Leprosy & 39 & 0 \\
\hline Typhus & 138 & 0 \\
\hline Kala azar & 18 & 0 \\
\hline Echinococcosis & 283 & 0 \\
\hline Filariasis & 0 & 0 \\
\hline Infectious diarrhea ${ }^{\dagger}$ & 109,407 & 2 \\
\hline Hand, foot and mouth disease & 59,143 & 1 \\
\hline Total & 475,076 & 1,766 \\
\hline
\end{tabular}

\footnotetext{
The data were from the website of the National Health Commission of the People's Republic of China.

${ }^{\dagger}$ Infectious diarrhea excludes cholera, dysentery, typhoid fever and paratyphoid fever.

The number of cases and cause-specific deaths refer to data recorded in National Notifiable Disease Reporting System in China, which includes both clinically-diagnosed cases and laboratory-confirmed cases. Only reported cases of the 31 provincial-level administrative divisions in the mainland of China are included in the table, whereas data of Hong Kong Special Administrative Region, Macau Special Administrative Region, and Taiwan are not included. Monthly statistics are calculated without annual verification, which were usually conducted in February of the next year for de-duplication and verification of reported cases in annual statistics. Therefore, 12-month cases could not be added together directly to calculate the cumulative cases because the individual information might be verified via National Notifiable Disease Reporting System according to information verification or field investigations by local CDCs.
}

doi: $10.46234 / \mathrm{ccdcw} 2020.208$ 